\title{
Malignant transformation in a fatal case of giant cell tumour of the sacrum
}

\author{
JP Crew, M Flannery, B Manners, CJ Coates
}

\begin{abstract}
Summary
Most giant cell tumours can be treated by local surgery and only rarely are they life threatening. We report a case of a giant cell tumour of the sacrum causing irresectable and fatal small bowel obstruction following malignant transformation of the tumour. The role of radiotherapy in this transformation is discussed.
\end{abstract}

Keywords: giant cell tumour, malignant transformation, sacrum

\section{Case report}

A 14-year-old girl presented with a six-month history of right-sided thigh pain. On investigation she was found to have a large sacral lesion which, on open biopsy, was diagnosed as a giant cell tumour of bone. Following a course of $50 \mathrm{~Gy}$ radiotherapy given in 25 fractions over 39 days, magnetic resonance imaging (MRI) confirmed no change in tumour size. Subsequent treatment included embolisation, curettage and bone grafting following which a repeat MRI scan suggested that tumour clearance was complete.

Four years later she was admitted with small bowel obstruction. At laparotomy a $10 \mathrm{~cm}$ mesenteric plaque of recurrent tumour was found. This arose from the sacrum and was encasing a loop of ileum indicating that this was the result of local infiltration rather than metastatic spread. A small bowel resection and primary anastomosis was performed. Within three months she developed further small bowel obstruction and MRI revealed extensive spread of the tumour retroperitoneally to involve the liver therefore preventing curative resection. The patient's condition rapidly deteriorated and she subsequently died.

Royal Surrey County Hospital, Egerton

Road, Guildford GU2 5XX, UK

JP Crew

M Flannery

B Manners

CJ Coates

Correspondence to

Mr JP Crew FRCS, Urology Registrar, Department of Urology, Churchill Hospital Headington, Oxford, UK

Accepted 21 October 1994

\section{Histopathology}

The initial biopsy specimen showed features of typical giant cell tumour of bone (figure 1), displaying a mixture of osteoclastic giant cells and uniform spindle stromal neoplastic cells, the latter exhibiting occasional typical mitoses. No area of aggressive histological pattern was seen. The appearance of the recurrent mesenteric and small bowel tumour (figure 2) was markedly different. This displayed a herring bone pattern of hypercellular, pleomorphic spindle celled sarcoma, with abundant atypical mitoses (figure 3). A few reactive osteoclastic giant cells were seen but there were no tumour giant cells and no tumour bone or cartilage was identified.

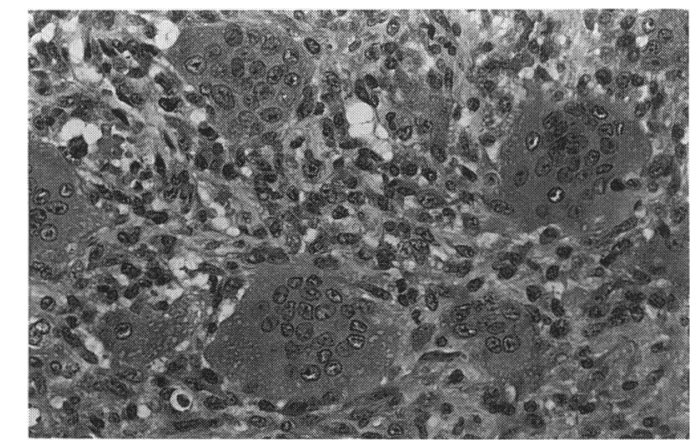

Figure 1 Typical giant cell tumour in the initial sacral biopsy $(\mathrm{H} \& \mathrm{E}, \times 400)$

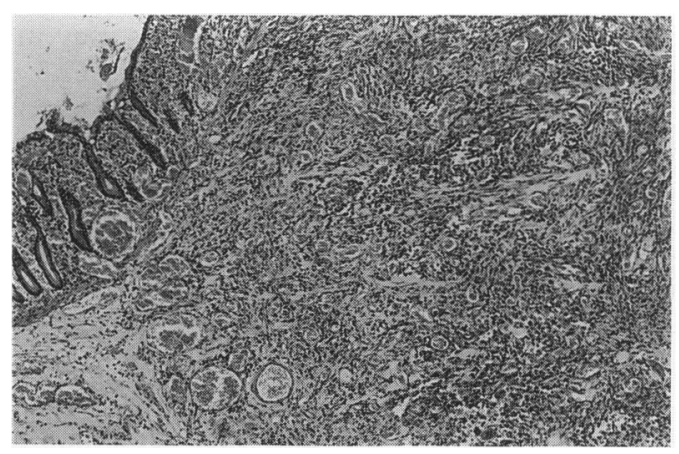

Figure 2 Ulcerated small intestinal mucosa invaded by recurrent tumour (lower right corner) $(\mathrm{H} \& \mathrm{E}, \times 25)$

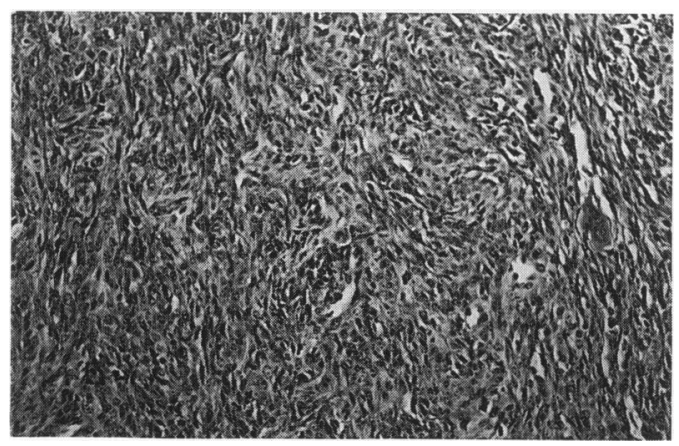

Figure 3 High grade fibrosarcoma in recurrent tumour with scanty reactive giant cells $(\mathrm{H} \& \mathrm{E}, \times 200)$ 


\section{Discussion}

Giant cell tumours of bone account for $5 \%$ of primary bone tumours ${ }^{1}$ and an incidence of one case per five years per District General Hospital in the UK. They exhibit a spectrum of clinical behaviour from benign to frankly malignant with a capacity for local recurrence and tissue infiltration. ${ }^{1-3}$ One to two per cent metastasize; however such spread may be from histologically benign lesions, with the metastases showing a benign growth pattern that responds favourably to surgical resection. ${ }^{1,2}$

The aim of surgery is complete excision. Where anatomically impractical other treatment options need to be considered, including radiotherapy. However radiotherapy carries the risk of sarcomatous change, restricting its use to tumours inaccessible to surgery. ${ }^{4}$ Sacrectomy has been successful for sacral giant cell tumours, but with considerable morbidity due to faecal and urinary incontinence, and may not be curative if there is pelvic extension. In the case reported total excision would have required sacrectomy or hemicorporectomy, both of which were discussed with, but rejected by the patient and family.

Eighty per cent of cases of giant cell tumours occur in long bones and are often amenable to surgical excision. ${ }^{1-3}$ The axial skeleton accounts for only $8 \%$ of cases but these are responsible for considerable mortality and morbidity due to involvement of the spinal cord and other neural structures.

Only $4 \%$ of giant cell tumours of bone arise in the sacrum ${ }^{1}$ making the tumour very rare. Peritoneal and intestinal invasion causing small bowel obstruction has not previously been described as a complication of giant cell tumours, this may in part be due the rarity of axial tumours. The extent of invasion in our case is apparent histologically with tumour cell infiltration of the coelomic cavity and full thickness through the intestinal mucosa emphasising the locally invasive nature of the tumour.

Sarcomatous change in a previously histologically typical giant cell tumour is seen in less than $1 \%$ of cases without previous radiotherapy but of those irradiated $10 \%$ undergo sarcomatous transformation. ${ }^{4}$ The dose of radiation in our case was greater than the $40 \mathrm{~Gy}$ reported by Boriani et $a l^{4}$ to be

1 Mirra JM. Bone tumours: clinical, radiologic and pathologic correlations. Vol 2. Philadelphia: Lea and Febiger, 1989; pp 942-1020.

2 Sanerkin NG. Malignancy, aggressiveness and recurrence in giant cell tumour of bone, Cancer 1980; 46: 1641-9.

3 McDonald MD, Sim FH, Mcleod RA, Dahlin DC. Giantcell tumour of bone. $\mathcal{f}$ Bone foint Surg $(\mathrm{Am})$ 1986; 68-A: 235-42.

\begin{tabular}{|c|c|}
\hline $\begin{array}{l}\text { Giant ce } \\
\text { features }\end{array}$ & tumours: clinical \\
\hline $\begin{array}{l}\text { Incidence: } \\
\text { Age: }\end{array}$ & $\begin{array}{l}5 \% \text { of all primary bone tumours } \\
80 \% \text { above } 20 \text { years old } \\
\text { mean age } 33 \text { years old } \\
35 \% \text { between } 20 \text { and } 30 \text { years old } \\
\text { female } \text { redominance }\end{array}$ \\
\hline $\begin{array}{l}\text { Sex: } \\
\text { Site: }\end{array}$ & $\begin{array}{l}80 \% \text { in long bones } \\
50 \% \text { around the knees } \\
\text { epiphysis greater than metaphysis } \\
\text { occasionally multiple sites }\end{array}$ \\
\hline Radiology: & $\begin{array}{l}\text { eccentric position } \\
\text { bone expansion } \\
\text { thinned cortex } \\
\text { radiolucent } \\
\text { fine trabeculation }\end{array}$ \\
\hline
\end{tabular}

Box 1

Giant cell tumours: histological features

Macroscopic pathology:

greyish, soft, fleshy tissue

areas of haemorrhage

cyst formation

Microscopic pathology:

moderately vascularised stroma

plump stomal cells with abundant cytoplasm

occasional spindly and elongated stromal cells

abundant uniformly distributed giant cells

Malignancy:

spectrum of malignancy

$1-2 \%$ metastasis

increased risk of sarcomatous transformation

following irradiation (2-29\%)

Box 2

associated with a $29 \%$ incidence of sarcomatous change. The evidence indicates transformation of a typical giant cell tumour of uncertain malignant potential into a fibrosarcoma of high grade malignancy, in the four years following radiotherapy. The history together with the occurrence of the sarcoma in the area of local irradiation suggest that the transformation was radiation induced. The case conveys further confirmation of the relative insensitivity of giant cell tumours to radiotherapy and the problems associated with treating axial giant cell tumours.

4 Boriani S, Sudanese A, Baldini N, Picci P. Sarcomatous degeneration of giant cell tumours. Ital $\mathcal{F}$ Orthop Traumato 1986; 12: $191-9$. 